\title{
Direct Reprogramming of Cardiac Fibroblasts to Repair the Injured Heart
}

\author{
Emma Adams ${ }^{1,+}$, Rachel McCloy ${ }^{1,+}$, Ashley Jordan ${ }^{1,+}$, Kaitlin Falconer ${ }^{1,+}$ and Iain M. Dykes ${ }^{1,2, *(D)}$ \\ 1 Pharmacy and Biomolecular Science, Liverpool John Moores University, Liverpool L3 3AF, UK; \\ emmaadams1@live.com (E.A.); rachel.mccloy@hotmail.com (R.M.); ashleyjordan1997@hotmail.co.uk (A.J.); \\ kdafalconer@gmail.com (K.F.) \\ 2 Liverpool Centre for Cardiovascular Science, Liverpool John Moores University, Liverpool L3 3AF, UK \\ * Correspondence: i.m.dykes@ljmu.ac.uk \\ $\dagger$ These authors contributed equally to this work.
}

check for

updates

Citation: Adams, E.; McCloy, R.; Jordan, A.; Falconer, K.; Dykes, I.M Direct Reprogramming of Cardiac Fibroblasts to Repair the Injured Heart. J. Cardiovasc. Dev. Dis. 2021, 8, 72. https://doi.org/10.3390/ jcdd 8070072

Received: 14 May 2021

Accepted: 18 June 2021

Published: 22 June 2021

Publisher's Note: MDPI stays neutral with regard to jurisdictional claims in published maps and institutional affiliations.

Copyright: (c) 2021 by the authors. Licensee MDPI, Basel, Switzerland. This article is an open access article distributed under the terms and conditions of the Creative Commons Attribution (CC BY) license (https:// creativecommons.org/licenses/by/ $4.0 /)$.

\begin{abstract}
Coronary heart disease is a leading cause of mortality and morbidity. Those that survive acute myocardial infarction are at significant risk of subsequent heart failure due to fibrotic remodelling of the infarcted myocardium. By applying knowledge from the study of embryonic cardiovascular development, modern medicine offers hope for treatment of this condition through regeneration of the myocardium by direct reprogramming of fibrotic scar tissue. Here, we will review mechanisms of cell fate specification leading to the generation of cardiovascular cell types in the embryo and use this as a framework in which to understand direct reprogramming. Driving expression of a network of transcription factors, micro RNA or small molecule epigenetic modifiers can reverse epigenetic silencing, reverting differentiated cells to a state of induced pluripotency. The pluripotent state can be bypassed by direct reprogramming in which one differentiated cell type can be transdifferentiated into another. Transdifferentiating cardiac fibroblasts to cardiomyocytes requires a network of transcription factors similar to that observed in embryonic multipotent cardiac progenitors. There is some flexibility in the composition of this network. These studies raise the possibility that the failing heart could one day be regenerated by directly reprogramming cardiac fibroblasts within post-infarct scar tissue.
\end{abstract}

Keywords: reprogramming; stem cell; regenerative medicine; induced pluripotent stem cell; myocardial infarction; heart failure

\section{Introduction}

Myocardial infarction (MI; commonly known as a heart attack) is one of the leading causes of mortality and morbidity in the Western world. MI is caused by occlusion of a coronary artery leading to ischaemic myocardial cell death. Remodelling of the myocardium following a myocardial infarction results in the formation of a fibrotic scar leading to subsequent heart failure, and this is a significant cause of mortality amongst survivors of myocardial infarction [1-3].

Recent advances in regenerative medicine have raised the possibility that this scar tissue itself could be used as the basis for the restoration of function. We now understand that cell fate is not irreversibly determined during embryonic development but that the epigenetic mechanisms that maintain cell fate in a structure such as the heart can be reversed using the tools of molecular biology. Fifteen years ago, it was demonstrated that a fully determined somatic cell, such as a skin fibroblast, could be converted by driving expression of four transcription factors into an induced pluripotent state resembling an embryonic stem cell, from which any somatic cell type could subsequently be differentiated [4]. This technology, in turn, subsequently led to efforts to directly convert one somatic cell type into another in a process known as transdifferentiation [5-7]. These efforts offer the possibility that in myocardial infarction patients, fibrotic scar tissue could one day be induced to 
transdifferentiate into functional myocardium, reversing heart failure and improving both quality of life and survival rates.

In this review, we will describe the molecular mechanisms that specify the major cardiac cell types in the embryo and use this as a framework to understand attempts to change cell fate in regenerative medicine. Many transcription factors, as well as other regulators of gene expression such as micro RNA, have been repurposed for therapeutic applications in an attempt to convert the scar tissue that forms during remodelling following a myocardial infarction into contractile tissue to restore the function of the heart. We will provide an overview of the many methods used and comment on the current state of the field.

\section{Embryonic Development of the Heart}

\subsection{Cellular Composition of the Adult Heart}

Cardiomyocytes, the force-producing contractile muscle of the heart, make up about $70-85 \%$ of the volume of the heart but only around a third of the total cell number [8]. The adult human heart contains as many as nine major cell types and 20 sub-types [8]. Cardiomyocytes are characterised by expression of contractile filaments within the sarcomere comprising proteins such as myosin heavy chain (MYH7, MYH6), cardiac alpha actin (ACTC1), alpha actinin (ACTN1), myomesin (MYOM1, MYOM2), titin (TTN), and troponin (TNNT2, TNNI3, TNNC1). The regulation of these genes is complex, and many exhibit isoform-specific changes during cardiomyocyte maturation [9-11]. Cardiomyocytes within the adult heart are not a homogenous population. There are, for example, differences between ventricular and atrial cardiomyocytes, while specialised cardiomyocytes form the conduction system.

Non-cardiomyocytes make up the majority of cells within the heart. These are essential for its function, providing structure through secretion of the extracellular matrix, providing the vascular supply and mediating homeostasis. Recent advances in single-cell RNA sequencing have allowed us to map the diversity of cell types within the heart based on transcriptional profiling and to follow changes during embryonic development and in disease $[12,13]$. Estimates of the precise proportions of each cell type vary, and there may be species differences [14].

Cardiac fibroblasts provide structural support through secretion of type I fibrillar collagen, forming a matrix in which is embedded the cardiomyocytes [15]. Cardiac fibroblasts also have a remarkable ability to sense and respond to stress or injury (discussed below). Fibroblasts are a molecularly heterogeneous population of cells with a gene expression profile overlapping multiple cell types ${ }^{16}$. Indeed, a lack of specific markers has impaired their study [16]. Genes expressed by fibroblasts include THY1/CD90, the intermediate filament vimentin and various collagens. Surprisingly, cardiac fibroblasts also express many transcription factors shared with cardiogenic precursors, including GATA4, NKX2.5, and MEF2C [17].

Other non-cardiomyocyte cell types include those comprising the vascular system of the heart (endothelium, pericytes, and vascular smooth muscle) and the immune system, including all types of leukocytes, as well as a large population of resident macrophages [18].

\subsection{Fate Specification and Lineage Restriction during Embryonic Heart Development}

During embryogenesis, the developmental potential (potency) of a cell is gradually restricted as it becomes committed to a specific lineage. The embryo is derived from pluripotent stem cells residing within the inner cell mass of the blastocyst. These cells contain open chromatin in an unmethylated state. As development proceeds, alternative cell fates are permanently closed through DNA methylation [19] and chromatin remodelling [20], resulting in the production of heterochromatin. Cell fate is largely regulated by transcription factors that recruit epigenetic modifiers such as chromatin remodelling complexes.

One of the earliest events in embryonic development is the lineage restriction event producing the three primary germ layers: the endoderm, mesoderm, and ectoderm. Most cardiovascular cell types are derived from the mesoderm germ layer. Within the mesoderm 
lineage, the next fate restriction divides this population into paraxial, intermediate, and lateral plate mesoderm; the lateral plate mesoderm is then physically divided by formation of the coelom into splanchnic (or visceral) and somatic mesoderm [21].

Cardiomyocytes have a single embryonic origin, being derived from a region of the splanchnic mesoderm known as the pre-cardiac mesoderm (Figure 1a). The transcription factor MESP1 is the earliest marker of multipotent cardiac progenitors and is expressed in some cells as they migrate from the primitive streak [22]. The precise function of MESP1 is unclear [23-26], but there is no master regulator of the cardiomyocyte lineage akin to MYOD in skeletal muscle and MESP1 alone is insufficient to specify cardiac progenitors [27]. Specification appears, instead, to depend not on a single transcription factor, but on a network of interacting factors activated downstream from MESP1 [28-31]. MESP1+ cells give rise at different timepoints to two distinct progenitor populations, the first and second heart fields [32], which may be distinguished on the basis of a distinct but overlapping expression profile (Figure 1b). The transcription factors NKX2.5 [33] and GATA4 [34] are common to both populations, while the primary field additionally expresses TBX5 [35] and the secondary field expresses MEF2C [36] and ISL1 [37]. However, it should be noted that each of these factors is expressed in a broader domain and it appears to be the combination of factors that determine fate. For example, ISL1 is also expressed earlier in development in a proliferating cardiac progenitor population that gives rise to both first and second heart field lineages [38], while MEF2C is widely expressed in the embryo, its second heart field expression being driven by a specific cardiac enhancer [39].

It appears that one of the key events in cardiomyocyte specification is the repression of alternative muscle cell fates. The three contractile muscle types (cardiac, skeletal, and smooth) share many properties but commonly express different isoforms of related genes (e.g., myosins). Myocardin (MYOCD) is a transcriptional co-activator of the ubiquitously expressed transcription factor serum response factor (SRF) [40]. It is expressed in cardiac progenitors and in vascular smooth muscle. MYOCD is negatively regulated by the micro RNAs miR1 and miR133a, which are expressed in cardiac and skeletal muscle. High levels of MYOCD drive specification of smooth muscle in preference to cardiomyocytes [41].

Unlike cardiomyocytes, both cardiac fibroblasts and vascular smooth muscle may be derived from multiple lineages, which converge on a common cell fate (Figure 1a). Perhaps for this reason, both cell types are highly plastic and show an ability to transdifferentiate to a migratory state under certain conditions. Cardiac fibroblasts are a poorly defined population of cells of multiple embryonic origins [42]. About $80 \%$ of cardiac fibroblasts residing within the myocardium are derived from the outer layer of the heart, the epicardium, while the rest are largely derived from the endocardium $[43,44]$, specifically from valve endothelium. The epicardium is derived from the intermediate mesoderm lineage and appears to share a common origin and gene expression profile to the kidney [45], for example in expression of the Wilm's tumour transcription factor WT1. Multipotent progenitor cells known as epicardium-derived cells (EPDCs) migrate into the heart in mid gestation where they differentiate into multiple cell types including fibroblasts, endothelium, and smooth muscle [45]. In contrast, the endothelium is derived from the lateral plate mesoderm and shares a common origin with haematopoietic lineages, both being derived from a common precursor, the haemangioblast $[46,47]$.

A minority of cardiac cells arise from an extra-mesodermal origin. The ectoderm lineage forms the neural crest, a population of multipotent progenitor cells that arises on the edge of the neural plate and migrate to various parts of the body. The cardiac neural crest migrates into the forming heart tube to populate the outflow tract and contributes to smooth muscle and vascular endothelium [48]. 


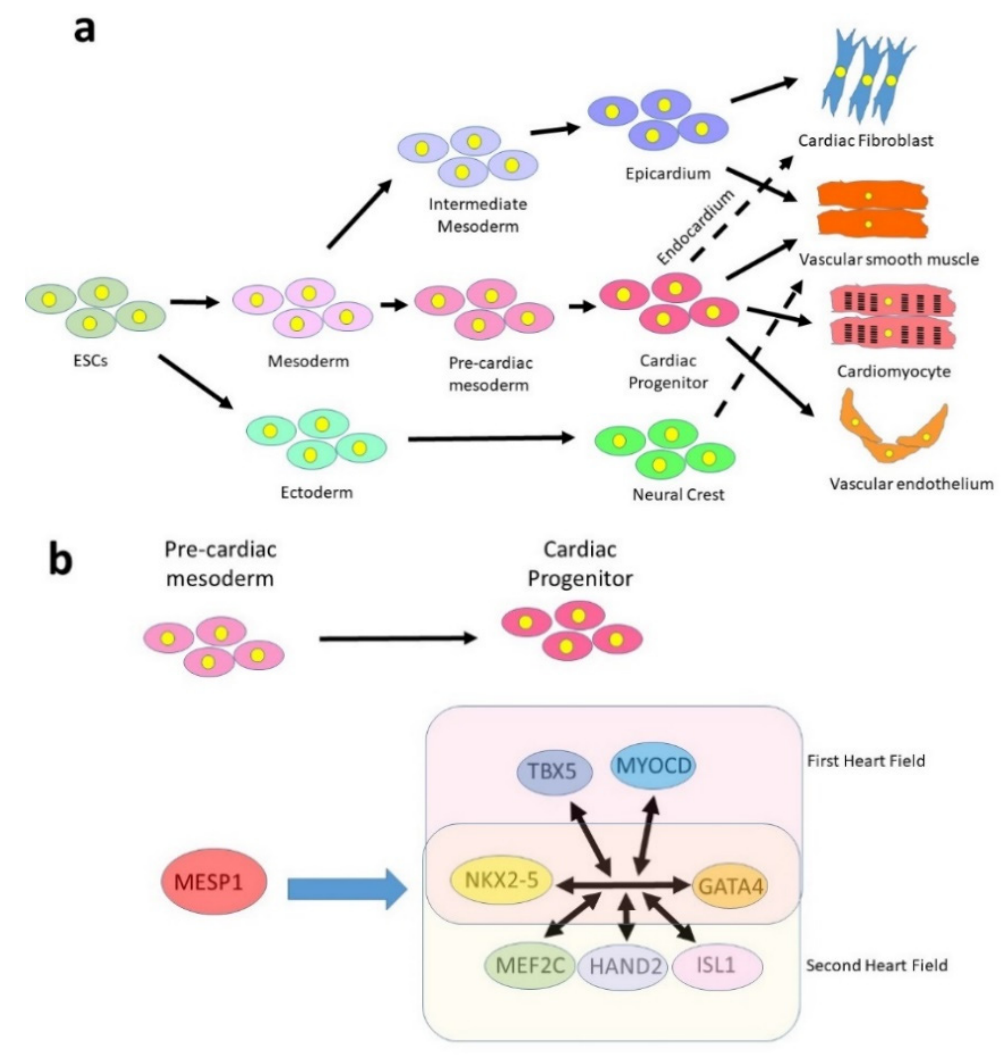

Figure 1. Embryonic development of the cardiovascular lineages. (a) Cardiomyocytes are derived from a multipotent cardiac progenitor of mesodermal origin, which also produces vascular smooth muscle, endothelium and cardiac fibroblasts (via the endocardium). Most cardiac fibroblasts, however, are derived from the epicardium, which can also generate smooth muscle. The neural crest, of ectodermal origin, contributes some smooth muscle as well as other cell types not shown in the diagram (valve interstitial cells, neurons and great artery fibroblasts). (b) Simplified version of the cardiogenic network that specifies cardiogenic progenitors. GATA4 and NKX2-5 are expressed in all progenitors, while other factors are expressed only in the first or second heart fields.

\section{Cellular Events Resulting from Myocardial Infarction}

\subsection{Initial Inflammatory Response}

Occlusion of a coronary artery leads to ischaemic myocardial cell death. Death occurs by both necrosis and apoptosis and is observed both within the infarct itself and within the surrounding region. Cell death peaks within the first $24 \mathrm{~h}$ after infarction, although low levels of cell death persist for several months as cardiac remodelling progresses [49].

An inflammatory response leads to activation of the innate immune system within minutes of an infarction. Necrotic cardiomyocytes themselves release a number of signals into the circulation collectively known as damage-associated molecular patterns (DAMPs) [18]. Inflammatory cytokines are also produced by a range of resident cells including macrophages, mast cells, fibroblasts and surviving cardiomyocytes. For example, cardiomyocytes produce interleukin-6 [50], while macrophages produce CXCL8 [51]. These signals serve to recruit circulating neutrophils and monocytes into the heart, where they differentiate into macrophages and phagocytose necrotic cells.

After several days, inflammation is reduced, neutrophil numbers drop, and the injured heart enters a reparative phase, mediated by macrophages [18]. Macrophages release VEGF to promote angiogenesis and TGF $\beta$, which has many functions but crucially activates and recruits fibroblasts into the heart [52]. Thus, this is a temporary phase, but initiates the start of fibrosis, leading to permanent changes in the heart. 


\subsection{Fibrosis}

Primitive vertebrates such as the zebrafish $[53,54]$, together with neonatal mammals [55], are able to regenerate the heart following injury. In these cases, little or only transient scarring is observed prior to regeneration, and a dampened immune response is seen. In contrast, the adult mammalian heart is unable to regenerate and therefore a damage limitation strategy is employed, which involves the process of fibrosis. Fibrosis is the replacement of dead contractile tissue with live connective tissue, fibroblasts, in order to maintain structural integrity. This repair, which is initially beneficial, becomes pathogenic when it results in uncontrolled deposition of ECM protein and scar tissue formation [56].

Cardiac fibroblasts are much less sensitive to ischaemia than cardiomyocytes and generally survive an infarction. In addition to endogenous cardiac fibroblasts, fibroblasts of multiple origins are recruited into the heart upon injury. This includes lineages that do not contribute cardiac fibroblasts during embryogenesis, such as haematopoietic bone marrow-derived cells $[57,58]$.

Fibroblasts have a remarkable ability to undergo transdifferentiation. TGF $\beta$ signalling serves not only to recruit fibroblasts into the heart, but also acts to phenotypically transform them to become myofibroblasts [59]. These are cells that combine features of a fibroblast and a smooth muscle cell; they are able to secrete large amounts of extracellular matrix proteins such as collagen, but also have contractile ability through the expression of $\alpha$ smooth muscle actin (ACTA2) microfilaments [60,61]. Myofibroblasts are normally absent in healthy myocardium, but become highly abundant shortly after injury [60]. Although it was previously thought that these cells are derived from the migratory fibroblasts recruited into the heart upon injury, it is now thought that the majority of activated myofibroblasts are derived from transdifferentiated resident cardiac fibroblasts from the epicardial lineage [16]. Transdifferentiation of fibroblasts is generally regarded as a twostep process. Fibroblasts initially differentiate into a highly proliferative form known as an activated fibroblast [16]. These cells contribute to the innate immune response removing damaged tissue through both the recruitment of monocytes (by secretion of inflammatory cytokines and chemokines), and secretion of matrix metalloproteinases, which act to degrade the extracellular matrix, releasing damaged or dead cardiomyocytes for phagocytic clearance [62]. While it was previously believed that scar tissue collagen is deposited only by activated myofibroblasts, recent genomics analysis performed in the mouse suggests that macrophages also directly contribute collagen [63].

\subsection{Progression to Heart Failure}

Heart failure is a progressive loss of efficiency of the heart. Structural and functional remodelling of the heart as a response to stress and can be seen, for example, in response to exercise. However, pathological remodelling is a response to disease and results in deposition of extracellular matrix coupled with cardiomyocyte necrosis [64]. Although scar formation is initially beneficial to the heart, persistent myofibroblasts lead to an accumulation of fibrous tissue [15]. This, in turn, leads to progressive adverse myocardial remodelling [15]. Heart failure due to pathological fibrotic remodelling is a major cause of mortality in survivors of myocardial infarctions $[65,66]$, and this is the reason why regeneration of the myocardium and reversal of fibrosis is so important.

\section{Regenerative Medicine}

Regenerative medicine holds much promise for repair of the injured heart. Reprogramming through forced expression of transcription factors has been shown to reverse epigenetic silencing of the genome leading to a state of induced pluripotency (Section 4.1). The same technology has been adapted to directly reprogramme somatic cells from one fate to another, bypassing the pluripotent state (Section 4.2). Such approaches raise the possibility that cardiac fibroblasts within post-infarct scar tissue could be converted into cardiomyocytes to reverse pathological remodelling. In this section, we will first describe 
the principles of induced pluripotency before going on to discuss direct reprogramming in the heart.

\subsection{Induced Pluripotent Technology}

Pluripotency in the embryo is determined and maintained, not by a single transcription factor, but by a network of transcription factors that includes at its core OCT4, SOX2, and NANOG [67]. The network appears to operate by synergistic mutual activation of members of the core network together with repression of genes promoting differentiation. The three core factors cooperatively bind to regulatory elements of target genes [67]. Multiple levels of pluripotency exist spanning the range from naïve to primed pluripotency [68], this latter state being that of the post-implantation epiblast.

As development proceeds, these cells lose potency to become firstly multipotent stem cells such as the cardiac progenitors described above and ultimately to become fully differentiated cells. Fate specification was for a long time considered to be an irreversible process, as described in Waddington's famous analogy of a ball rolling downhill through an epigenetic landscape of bifurcating valleys [69]. This notion was overturned in 2006 when it was shown that a differentiated cell type (mouse fibroblasts) could be "reprogrammed" back to a pluripotent state [4]. Takahashi and Yamanaka screened a panel of 24 candidate genes (selected either for their expression in embryonic stem cells or oncogenic properties) for their ability to reprogramme. Retroviral expression of all 24 factors successfully induced pluripotency as demonstrated by upregulation of an Fbx15 reporter gene. By progressively eliminating factors, Takahashi and Yamanaka were able to identify a minimum network of just four factors required for reprogramming, which have become known as the Yamanaka or OKSM factors: the ESC transcription factors OCT3/4 and SOX2, and the oncogenes cMYC and KLF4. These same factors were subsequently shown to reprogramme human dermal fibroblasts to a pluripotent state [70].

Thus, as is the case for embryonic cardiogenic specification, there is no single factor determining pluripotency, but rather a network of synergistic interacting factors performs this function. The precise makeup of the network appears to be somewhat flexible, as demonstrated by the observation that the oncogenes MYC and KLF4 can be substituted for NANOG and LIN28A [71]. The requirement for LIN28A is particularly interesting because this gene is not a transcription factor, but rather has a post-transcriptional function. LIN28A is an RNA-binding protein that can regulate both the processing of micro RNA (mIR) from precursors and the translation of coding mRNAs [72].

A number of groups have improved upon the original reprogramming methods, particularly in order to improve safety and translational clinical potential by reducing the potential for tumour formation. Methods include the use of non-integrating episomal plasmids derived from the Epstein-Barr virus [73,74], the use of mRNA [75], or the use of small molecules [76].

\subsection{Direct Reprogramming of Cardiac Fibroblasts}

The work of Yamanaka's group and others opened the door to personalised medicine. It was now possible, in theory at least, to take a skin biopsy from a patient and use this to generate an induced pluripotent stem cell (iPSC), which could then be differentiated in vitro into cardiovascular cell types using growth factors present in the embryo such as Nodal/Activin, FGF2 and BMP4 [77] (Figure 2). Such differentiated cells can be seeded onto a decellularised scaffold to generate a patch of tissue that may grafted during surgery. This has proven useful in the repair of some congenital heart diseases such as ventricular septal defect or valve replacement [78]. Many groups are also investigating the use of such patches to repair myocardial infarction. For example, Wang et al. seeded human iPSC-derived cardiomyocytes and fibroblasts onto a decellularised matrix and demonstrated that this patch reduced infarct size and improved cardiac function in a rat model of MI [79]. Su et al. used a microfluidics approach to engineer a network of blood vessels made from human umbilical cord endothelial cells, before seeding this with iPSC-derived cardiomyocytes [80]. 
An alternative approach, and the subject of this review, is that cardiac fibroblasts residing within the scar tissue itself might be reprogrammed in vivo to achieve regeneration of the injured myocardium.

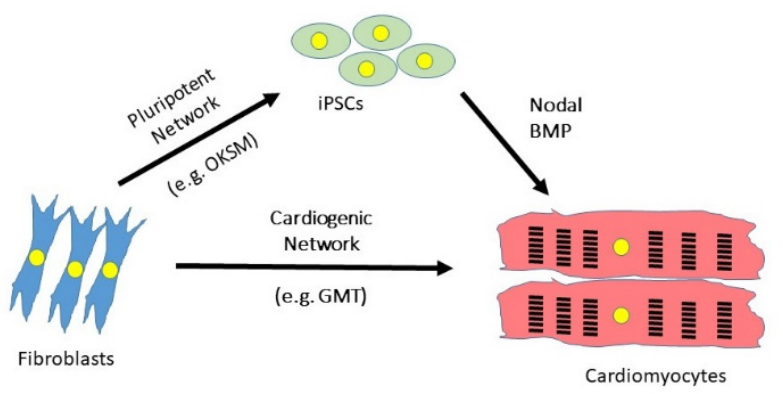

Figure 2. Strategies to differentiate fibroblasts into cardiomyocytes. Synergistic networks of transcription factors may be used either to reprogramme fibroblasts back to a pluripotent state from which cardiomyocytes can be differentiated by recapitulating embryonic development, or by direct reprogramming from one differentiated state to another. OKSM = OCT3/4, KLF4, SOX2, cMYC; GMT = GATA4, MEF2C, TBX5.

To reverse the process of lineage specification and revert a cell to a state of pluripotency requires that heterochromatin be converted back to euchromatin through demethylation of DNA and acetylation of histone. Direct reprogramming or transdifferentiation from one differentiated cell type to another, bypassing the pluripotent stage, requires slightly different chromatin remodelling. Heterochromatic regions of the genome specifying the desired cell fate must be selectively opened up, while those specifying the old fate must be silenced. Such binary switches in cell fate are observed in the embryo, for example, the gene regulatory network comprising MYOCD, miR1, and miR133a, appears to control the selection of one of the muscle fates (cardiac, smooth or skeletal) through repression of alternative cell fates [41] (discussed above).

Fibroblasts are particularly attractive targets for direct reprogramming efforts because they are a naturally plastic cell type with the ability to transdifferentiate under certain conditions (Section 3.2). Cardiac fibroblasts, in addition, share considerable gene expression with cardiac progenitors, including many transcription factors of the cardiogenic network [17].

\subsection{Identification of a Cardiogenic Network in Mouse Models}

Ieda et al. [81] from Deepak Srivistava'a lab used a strategy similar to that previously used by Takahashi and Yamanaka by generating a transgenic reporter mouse that could be used to monitor fate specification. Ieda et al. chose to use MYH6 ( $\alpha$ myosin heavy chain) as a marker of mature cardiomyocytes. The reader will recall that the regulation of the myosin heavy chain genes is complex. This family of genes demonstrates species and muscle type differences, in addition to being subject to developmental isoform switching [11,82]. In the human heart MYH6 is largely restricted to the atria while MYH7 is expressed in the ventricles, although there is some co-expression during embryonic development [83]. In mice, both MYH6 and MYH7 are co-expressed in the early heart tube, in later embryos the atrial/ventricular dichotomy seen in the human heart is transiently observed, before MYH6 becomes the dominant pan-cardiomyocyte marker in the postnatal heart [84]. Thus, it is not entirely correct that MYH6 expression is a reporter of the mature cardiomyocyte cell fate in mice as it is expressed as early as embryonic day 7.5 [84]. Nevertheless, this reporter has been subsequently used in many rodent studies (Tables 1 and 2).

Ieda et al. [81] screened a pool of 14 transcription factors known to be expressed in cardiac progenitors for their ability to transdifferentiate fibroblasts. Ieda et al. gradually removed factors from this pool to identify the minimum combination sufficient for reprogramming. This work confirmed that MESP1 is insufficient for reprogramming, and 
indeed MESP1 is not present within the identified combination. Instead, they found that three factors GATA4, MEF2C, TBX5 (herein referred to as GMT) are: required. Thus, as in embryonic development, the cardiac lineage is not specified by a single factor, but by a synergistic network of cardiogenic factors. One interesting feature of this network is that it includes factors expressed largely in the first heart field (TBX5) and the second heart field (MEF2C) as well as one shared factor (GATA4). TBX5 has, however, been shown to be expressed in the posterior second heart field [85], where co-expression of all three factors occurs.

MEF2C and TBX5 have been shown to have properties of pioneer transcription factors, binding to regions of heterochromatin and facilitating chromatin remodelling to reactivate previously closed regions of the genome [86]. At the same time, enhancers active in fibroblasts are silenced [87]. MEF2C in particular appears to be a key element with MEF2 binding sites in the genome acting as sites of recruitment for multiple transcription factors [87]. In addition, the use of polycistronic expression constructs, which drive higher expression of MEF2C over GATA4 and TBX5, seem to be more efficient at reprogramming [88].

Another feature of the network is the importance of a combinatorial code for a specific cell fate $[86,87]$. Each transcription factor of the network is expressed in multiple cell types during development and therefore it is the specific combination of factors bound at a given locus that result in a specific outcome. Synergistic binding of transcription factors to target genes has been demonstrated, for example, in MEF2C and TBX5 to the target MYH6 [89].

As was found to be the case for the pluripotent network, the cardiogenic network exhibits flexibility, and a number of groups have subsequently demonstrated that a number of different combinations of factors achieve similar results. It would be impossible to discuss each of these in detail in a single review, but we have summarised the strategies used by these groups in Table 1. Table 2 summarises the results of these experiments. Most reprogramming combinations have at their core the GMT factors identified by Ieda. The Olson lab discovered that addition of a fourth transcription factor, HAND2, to the reprogramming cocktail improved efficiency [90] and the resulting GMHT cocktail has subsequently been used with various modifications in subsequent studies by the Olson [91-93], Song [94], and Gearhart $[95,96]$ labs. Protze et al. tested 120 different three factor combinations and found that many different triplets elicited some degree of reprogramming [97]. Seven factors were most commonly seen in these networks: GATA4, MEF2C, TBX5, MESP1, NKX2.5, and MYOCD [97].

Repression of the fibroblast cell fate through inhibition of either TGF $\beta$ or RhoA/ROCK signalling has been found to enhance the effectiveness of the cardiogenic network [92]. 


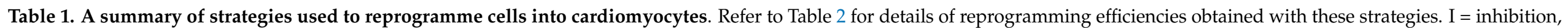
$\mathrm{A}=$ activation.

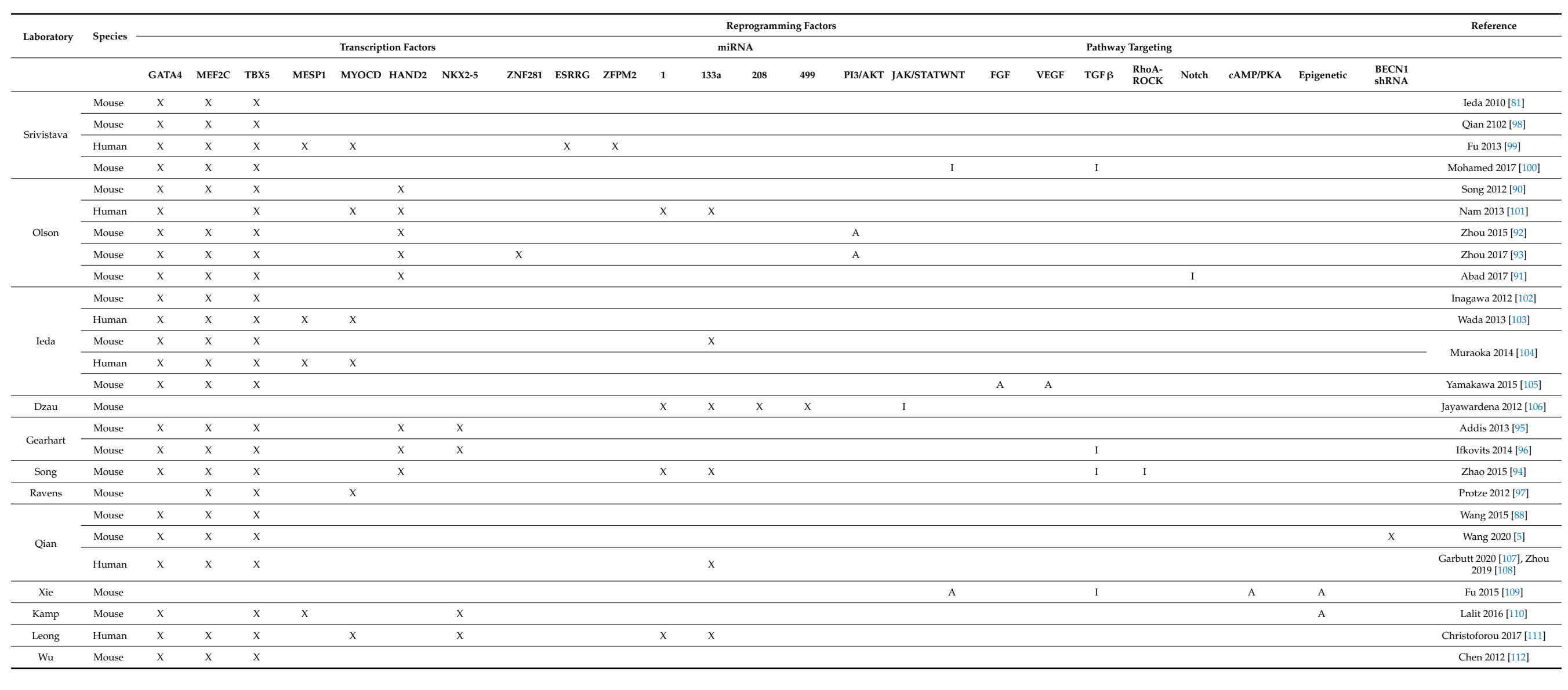




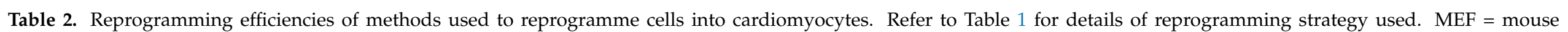
embryonic fibroblast.

\begin{tabular}{|c|c|c|c|c|c|c|c|}
\hline Laboratory & Species & In vitro/In Vivo & Source Cell & Developmental Stage & Reprogramming Efficiency & Comments & Reference \\
\hline \multirow{6}{*}{ Srivistava } & Mouse & In vitro & Cardiac Fibroblast & Postnatal & $20 \%$ express MYH6 at 10 days & $\begin{array}{l}\text { Although transdifferentiation is } \\
\text { rapid, maturation (gain of TNNT2) } \\
\text { takes several weeks }\end{array}$ & Ieda 2010 [81] \\
\hline & Mouse & In vivo & Cardiac Fibroblast & Adult & $10-15 \%$ & $\begin{array}{l}\text { Cells are more mature than those } \\
\text { reprogrammed in vitro }\end{array}$ & Qian 2012 [98] \\
\hline & \multirow{3}{*}{ Human } & \multirow{3}{*}{ In vitro } & Cardiac Fibroblast & Foetal & \multirow{3}{*}{$20 \%$ express MYH6 } & \multirow{3}{*}{$\begin{array}{l}\text { Report that GMT alone cannot } \\
\text { reprogramme human cells. }\end{array}$} & \multirow{3}{*}{ Fu 2013 [99] } \\
\hline & & & Dermal fibroblast & Neonatal & & & \\
\hline & & & $\begin{array}{l}\text { H9 ES-derived } \\
\text { fibroblast }\end{array}$ & $\mathrm{n} / \mathrm{a}$ & & & \\
\hline & Mouse & In vitro & Cardiac Fibroblast & Neonatal & $30 \%$ express MYH6 at 2 weeks & $\begin{array}{l}\text { Almost doubles efficiency over } \\
\text { GMT alone }\end{array}$ & Mohamed 2017 [100] \\
\hline \multirow{9}{*}{ Olson } & \multirow{3}{*}{ Mouse } & \multirow{2}{*}{ In vitro } & Cardiac fibroblast & Adult & $\begin{array}{c}\text { 6.8\% express both MYH6 and } \\
\text { TNNT2 }\end{array}$ & Efficiency is $1.4 \%$ with GMT alone & \multirow{3}{*}{ Song 2012 [90] } \\
\hline & & & Tail tip Fibroblast & Adult & $\begin{array}{l}\text { 9.2\% express both MYH6 and } \\
\text { TNNT2 }\end{array}$ & & \\
\hline & & In vivo & Cardiac Fibroblast & Adult & $\begin{array}{l}\text { At least } 10,000 \text { cells } \\
\text { transdifferentiated }\end{array}$ & $\begin{array}{l}\text { Improves heart function following } \\
\text { infarction }\end{array}$ & \\
\hline & Human & In vitro & Dermal fibroblast & Adult & $9.5 \%$ express TNNT2 & $\begin{array}{l}\text { Sarcomere structures and calcium } \\
\text { transients seen at } 4-11 \text { weeks }\end{array}$ & Nam 2013 [101] \\
\hline & \multirow{3}{*}{ Mouse } & \multirow{3}{*}{ In vitro } & MEF & Embryo & $\begin{array}{l}\sim 25 \% \text { express both MYH6 and } \\
\text { TNNT2 }\end{array}$ & \multirow{3}{*}{$\begin{array}{l}\text { Reprogramming more efficient in } \\
\text { embryonic than adult cells. }\end{array}$} & \multirow{3}{*}{ Zhou 2015 [92] } \\
\hline & & & Tail tip fibroblast & Adult & $\begin{array}{l}\sim 5 \% \text { express both MYH6 and } \\
\text { TNNT2 }\end{array}$ & & \\
\hline & & & Cardiac Fibroblast & Adult & $\begin{array}{l}\sim 6 \% \text { express both MYH6 and } \\
\text { TNNT2 }\end{array}$ & & \\
\hline & Mouse & In vitro & Tail tip fibroblast & Adult & $\begin{array}{l}\sim 28 \% \text { express both MYH6 and } \\
\text { TNNT2 after } 7 \text { days }\end{array}$ & $\begin{array}{l}\text { Suppresses inflammatory } \\
\text { signalling }\end{array}$ & Zhou 2017 [93] \\
\hline & Mouse & In vitro & MEF & Embryo & $\begin{array}{c}\text { Up to } 70 \% \text { express MYH6 and } \\
\text { TNNT2 or ACTN2 }\end{array}$ & $\begin{array}{l}\text { Improves efficiency of generation } \\
\text { of mature cardiomyocytes by } \\
\text { GMHT by 5-6 fold }\end{array}$ & Abad 2017 [91] \\
\hline
\end{tabular}


Table 2. Cont

\begin{tabular}{|c|c|c|c|c|c|c|c|}
\hline Laboratory & Species & In vitro/In Vivo & Source Cell & Developmental Stage & Reprogramming Efficiency & Comments & Reference \\
\hline \multirow{4}{*}{ Ieda } & Mouse & In vivo & Cardiac Fibroblast & Adult & $3 \%$ express MYH6 at 1 week & $\begin{array}{l}\text { Reprogramming efficiency is } \\
\text { lower than in other mouse in vivo } \\
\text { studies }\end{array}$ & Inagawa 2012 [102] \\
\hline & Mouse & In vitro & MEF & Embryo & $\sim 35 \%$ express MYH6 at 1 week & $\begin{array}{l}\text { Cardiomyocytes mature more } \\
\text { quickly than GMT alone }\end{array}$ & \multirow[t]{2}{*}{ Muraoka 2014 [104] } \\
\hline & Human & In vitro & Cardiac Fibroblast & Adult & $\sim 20 \%$ express TNNT2 at 1 week & & \\
\hline & Mouse & In vitro & MEF & Embryo & $\sim 70 \%$ beating cells at 4 weeks & & Yamakawa 2015 [105] \\
\hline \multirow{2}{*}{ Dzau } & Mouse & In vitro & Fibroblast & & $\begin{array}{c}1.5-7.7 \% \text { express MYH6 with miR } \\
\text { alone, increasing to } 28 \% \text { with JAK } \\
\text { inhibitor }\end{array}$ & $\begin{array}{l}\text { JAK inhibition dramatically } \\
\text { improves reprogramming using } \\
\text { miR }\end{array}$ & \multirow{2}{*}{$\begin{array}{c}\text { Jayawardena } 2012 \\
{[106]}\end{array}$} \\
\hline & Mouse & In vivo & Cardiac Fibroblast & Adult & $\begin{array}{l}\text { Induced cardiomyocytes represent } \\
\sim 1 \% \text { of total and express TNNT2 }\end{array}$ & & \\
\hline \multirow[t]{2}{*}{ Gearhart } & Mouse & In vitro & MEF & Embryo & $\begin{array}{l}\sim 1.5 \% \text { show calcium oscillations at } \\
2 \text { weeks }\end{array}$ & $\begin{array}{l}\text { Developed a quantifiable calcium } \\
\text { reporter to assay efficiency } \\
\text { HNGMT reported to be }>50 \text {-fold } \\
\text { more efficient than GMT alone }\end{array}$ & Addis 2013 [95] \\
\hline & Mouse & In vitro & MEF & Embryo & $\begin{array}{l}\sim 15 \% \text { show calcium oscillations at } \\
2 \text { weeks }\end{array}$ & $\begin{array}{c}\text { TGF } \beta \text { inhibition improves } \\
\text { efficiency } 5 \text { fold over HNGMT } \\
\text { alone }\end{array}$ & Ifkovits 2014 [96] \\
\hline \multirow{3}{*}{ Song } & \multirow{3}{*}{ Mouse } & \multirow{3}{*}{ In vitro } & MEF & Embryo & & & Zhao 2015 [94] \\
\hline & & & Cardiac Fibroblast & Adult & $\begin{array}{c}\text { Up to } 18 \% \text { express } \mathrm{TNNT} 2 \text { at } 4 \\
\text { weeks. } \\
2.5 \% \text { beating at } 5 \text { weeks }\end{array}$ & & \\
\hline & & & Tail tip fibroblast & Adult & $\begin{array}{c}\text { Up to } 20 \% \text { express TNNT2 at } 4 \\
\text { weeks. } \\
4 \% \text { beating at } 5 \text { weeks }\end{array}$ & & \\
\hline Ravens & Mouse & In vitro & MEF & Embryo & $2.5 \%$ express MYH6 & $\begin{array}{l}\text { Found that a number of triplet } \\
\text { combinations can be used. }\end{array}$ & Protze 2012 [97] \\
\hline
\end{tabular}


Table 2. Cont.

\begin{tabular}{|c|c|c|c|c|c|c|c|}
\hline Laboratory & Species & In vitro/In Vivo & Source Cell & Developmental Stage & Reprogramming Efficiency & Comments & Reference \\
\hline \multirow{7}{*}{ Qian } & Mouse & In vitro & Cardiac Fibroblast & Adult & $\begin{array}{c}\sim 10 \% \text { express MYH6, } \sim 5 \% \text { express } \\
\text { TNNT2 }\end{array}$ & $\begin{array}{l}\text { Demonstrated that expression of } \\
\text { GMT as polycistronic MGT } \\
\text { improves efficiency }\end{array}$ & Wang 2015 [88] \\
\hline & \multirow[t]{2}{*}{ Mouse } & In vitro & Tail tip fibroblast & Postnatal & $\sim 22 \%$ express TNNT2 (GMHT) & \multirow{3}{*}{$\begin{array}{l}\text { Use of Sendai virus improves } \\
\text { efficiency over retrovirus }\end{array}$} & \multirow{3}{*}{ Miyamoto 2018 [113 } \\
\hline & & In vivo & Cardiac Fibroblast & Adult & $\sim 1.5 \%$ express TNNT2 (GMT) & & \\
\hline & Human & In vitro & Cardiac Fibroblast & Adult & $\begin{array}{c}4 \% \text { express TNNT2 (GMTMM) } \\
\sim 15 \% \text { express TNNT2 } \\
\text { (GMTMM+miR133) }\end{array}$ & & \\
\hline & Mouse & $\begin{array}{l}\text { In vitro } \\
\text { (In vivo) }\end{array}$ & Cardiac Fibroblast & Adult & & $\begin{array}{l}\text { Becn1 shRNA knockdown } \\
\text { improves GMT efficiency }\end{array}$ & Wang 2020 [114] \\
\hline & Human & In vitro & $\begin{array}{l}\text { H9 ES-derived } \\
\text { fibroblast }\end{array}$ & $\mathrm{n} / \mathrm{a}$ & $40-60 \%$ express TNNT2 at 2 weeks & Very efficient streamlined cocktail & Garbutt 2020 [107] \\
\hline & Human & In vitro & Cardiac Fibroblast & Adult & $\sim 40 \%$ express TNNT2 at 2 weeks & & Zhou 2019 [108] \\
\hline \multirow{2}{*}{ Xie } & \multirow{2}{*}{ Mouse } & In vitro & MEF & Embryo & \multirow{2}{*}{$\begin{array}{c}14.5 \% \text { express ACTN2, } 9 \% \text { MYH6 } \\
\text { on day } 24\end{array}$} & & \multirow{2}{*}{ Fu 2015 [109] } \\
\hline & & In vitro & Tail tip fibroblast & Adult & & & \\
\hline \multirow[t]{2}{*}{ Kamp } & \multirow[t]{2}{*}{ Mouse } & In vitro & Lung fibroblast & Adult & \multirow[t]{2}{*}{$\sim 7.25$ colonies $/ 50,000$ cells } & \multirow{2}{*}{$\begin{array}{l}\text { This method generates } \\
\text { proliferating cardiac progenitor } \\
\text { cells }\end{array}$} & \multirow[t]{2}{*}{ Lalit 2016 [110] } \\
\hline & & In vitro & Tail tip fibroblast & Adult & & & \\
\hline Leong & Human & In vitro & Dermal fibroblast & Adult & Not stated & & $\begin{array}{c}\text { Christoforou } 2017 \\
\text { [111] }\end{array}$ \\
\hline \multirow[b]{2}{*}{$\mathrm{Wu}$} & \multirow[b]{2}{*}{ Mouse } & In vitro & Cardiac Fibroblast & $2-3$ weeks & No MYH6 expression at 3 weeks & \multirow[b]{2}{*}{$\begin{array}{l}\text { Data suggest GMT } \\
\text { reprogramming is inefficient }\end{array}$} & \multirow[b]{2}{*}{ Chen 2012 [112] } \\
\hline & & In vitro & Tail tip fibroblast & Adult & $\begin{array}{l}\text { No MYH6 expression but 35\% } \\
\text { express TNNT2 at } 3 \text { weeks }\end{array}$ & & \\
\hline
\end{tabular}




\subsection{Reprogramming Human Cells}

Human cells have proven to be more refractory to reprogramming than mouse cells, and not all findings in the rodent model have been found to be directly applicable to man. In particular, the GMT combination, which works well in mice, has been found to be insufficient to reprogramme human fibroblasts $[99,103]$. This impasse was overcome in 2013 when three different labs published three different methods for reprogramming human cells. The Srivistava lab used a reprogramming network of seven transcription factors (GATA4, MEF2C, TBX5, MESP1, MYOCD, ESRRG, and ZFPM2) [99], the Olson lab used a network of four transcription factors (GATA4, TBX5, MYOCD, and HAND2) together with two micro RNAs (miR-1 and miR-133a) [101], whilst leda's lab used a five factor network (GATA4, MEF2C, TBX5, MESP1, and MYOCD) [103]. Direct comparisons between the methods are difficult because each group used a slightly different method to assay reprogramming efficiency (Table 2).

\subsection{In Vivo Reprogramming of the Injured Heart}

Whereas most studies to date have been performed in vitro, the attraction of this technology is that it raises the possibility to reprogramme the injured heart in vivo, thus repairing the myocardium at the same time as reducing pathological remodelling. Reprogramming in vivo presents a new set of challenges, such as that of delivering the reprogramming factors to the correct cells and a much more variable cellular environment in which to induce such changes.

Four ground-breaking studies were published by different labs in close succession in 2012 (Tables 1 and 2).

Qian et al. [98], working in Srivastava's lab, and Inagawa et al. [102], working on Ieda's lab, independently demonstrated in vivo reprogramming of murine cardiac fibroblasts by retroviral delivery of GMT following myocardial infarction induced by coronary artery ligation. Qian et al. found that the retrovirus delivered to the myocardium bordering the infarct zone on the same day as infarction can transduce proliferating vimentin positive activated fibroblasts in the injured heart, but not non-proliferating cells such as resident cardiac fibroblasts in the normal heart. Whilst this could be seen as a limitation on the efficiency of reprogramming, it is advantageous to be able to target reprogramming specifically to the cells participating in remodelling, reducing off-target effects. Lineage tracing using periostin CRE revealed that ACTN1 positive induced cardiomyocytes were indeed derived from fibroblasts. Qian et al. found that although reprogramming efficiency $(10-15 \%)$ was similar to that observed in vitro, the induced cardiomyocytes produced were more mature in vivo and they had sarcomeric structures resembling endogenous cardiomyocytes. Statistically significant improvements in cardiac function were seen by 8-12 weeks in reprogrammed hearts relative to controls including in the ejection fraction, stroke volume and cardiac output.

Inagawa et al. [102] also transduced GMT using a retroviral vector immediately following coronary artery ligation. An MYH6 reporter was expressed in 3\% of viral infected cells after 2 weeks, a rate much lower than observed by Qian et al., and again only proliferating cells were targeted. Improvements in cardiac physiology were not investigated in this study.

Song et al. [90], working in Olson's lab, used a similar strategy to test in vivo reprogramming by injecting GMHT retrovirus immediately following coronary artery ligation. Lineage tracing using a different CRE line, the fibroblast-specific calcium-binding protein S100A4, confirmed transdifferentiation of proliferating fibroblasts. Assessment of cardiac physiology demonstrated a progressive reduction in fractional shortening and ejection fraction beginning $24 \mathrm{~h}$ after injury in controls. This loss of efficiency was reduced in GMHT hearts in the weeks following injury. By 12 weeks post-injury, stroke volume of GMHT treated animals exceeded that of unoperated controls, while ejection fraction approached this level. Thus, these animals showed a greater improvement in function than GMT treated animals. Fibrosis was also reduced. 
Jayawardena et al. [106], working in Dzau's lab, used a lentivirus to deliver four micro RNAs to the injured heart and were also able to demonstrate transdifferentiation of S100A4 CRE cells. This method did not improve cardiac function immediately after ligation but was shown to significantly improve fractional shortening and velocity of circumferential fibre shortening by $2-3$ months after injury [115].

The above studies utilise viral vectors that raise safety concerns regarding insertional mutagenesis, limiting their clinical applications. In 2015, Miyamoto et al. [113], working in Ieda's lab, tested the use of a non-integrating Sendai virus vector. This virus replicates in the cytoplasm and does not integrate into the host genome, expression of reprogramming factors is therefore transient and not inherited by daughter cells upon cell division. Surprisingly, Miyamoto et al. found that this vector improved both efficiency of reprogramming and maturation of the resulting cells when reprogramming using GMT. In addition, immunostaining revealed specific targeting of cardiac fibroblasts and not cardiomyoctes. Functional studies demonstrated significant improvements in ejection fraction and functional shortening relative to controls at 4 weeks as well as a significant reduction in fibrotic area. An alternative approach was taken by Chang et al., working in Kim's lab, who used gold nanoparticles coated with an arginine-rich peptide in order to deliver GMT to the mouse heart following coronary artery ligation [116]. This work demonstrated reduced fibrotic area and infarct thickness two weeks after injury.

Thus, in summary, results from a number of different groups have independently shown that cardiac function post infarction can be improved by reprogramming. Indeed, reprogramming in vivo tends to produce more mature cardiomyocytes than in vitro efforts, perhaps because the induced cardiomyocytes receive as-yet unidentified signals from their cellular environment within the tissue [117].

One caveat of these studies is that the mice used tend to be very young. Qian et al. used mice at 2 months old, while Song et al. used mice of 8-10 weeks. As mice reach sexual maturity at 6 weeks, these mice are therefore the equivalent of teenagers or young adults, whereas in man myocardial infarction is generally a disease affecting older people. As we know the murine heart maintains an intrinsic regenerative capacity in the neonatal period [55], and that embryonic cells are generally more easily reprogrammed in vitro [92] it is likely that reprogramming efficiency would be lower in an older heart.

\section{Discussion}

In this review, we have shown how a detailed understanding of cell fate determination during cardiovascular embryonic development has been utilised to inform strategies to reprogramme cardiac fibroblasts in the injured heart. As was found to be the case in the embryo, there is not a single transcription factor that can flip a switch between two differentiated cell states but rather acquisition of a cardiomyocyte fate appears to depend on a synergistic interaction between multiple factors. This network appears to be somewhat tolerant of substitutions, but there are species-specific differences.

It is perhaps noteworthy that almost a decade after in vivo reprogramming was first reported in a mouse model of myocardial infarction, there are as yet no published clinical successes and no current studies are listed in clinicaltrials.gov. This is indicative of the many challenges that remain to be overcome in the field before this potential can be realised in the clinic $[117,118]$. Two key issues remain unsolved. These are the low rate of observed reprogramming and safety concerns regarding the use of integrating viral vectors.

Determining the level of reprogramming required to obtain a clinically relevant outcome for patients is a key question. Most studies report a relatively low rate of reprogramming even in the young heart (Table 2), raising concerns that this may be insufficient to improve cardiac function in elderly patients. Nevertheless, evidence from mouse models has suggested that a relatively low level of reprogramming can result in a measurable improvement in cardiac function. For example, Qian et al. reported a significant improvement in ejection fraction and stroke volume with a reprogramming rate of $10-15 \%$ [98], while Song et al. found that the stroke volume of treated animals exceeded that of unoperated 
controls at 12 weeks [90]. We do not yet know whether the same effect would be seen in a patient and some have suggested a much higher level of reprogramming is needed, perhaps as high as 50\% [119]. Only the recently published streamlined method developed in the Qian lab has approached this level of efficiency, achieving a rate of 40-60\% [107,108], but this is an in vitro method that utilises a selectable marker for infected cells limiting its potential for translation. Perhaps a fruitful avenue for future basic research would be to study the relationship between reprogramming efficiency and functional recovery in the mouse MI model, or a more clinically relevant animal model such as the pig, in order to put a more precise figure on the required reprogramming threshold to inform future efforts. We also need more detailed data on the long-term impacts of reprogramming. How long do reprogrammed cells survive, are they epigenetically compromised in some way? Furthermore, all such studies to date have studied reprogramming in an acute model of myocardial infarction, studies on chronic heart failure models are lacking [120].

How can reprogramming efficiency be improved in vivo? In simple terms, this involves ensuring that the full complement of reprogramming factors is delivered to as many cells as possible and that these cells are receptive to those factors. Reprogramming appears to be effective only for dividing rather than quiescent cells $[53,90,98]$. To date, the virus has been delivered at the same time as the coronary artery is ligated in all in vivo mouse studies, but it may be that efficiency could be improved by treatment at a later stage when activated fibroblasts are at the peak of their proliferation, before their transdifferentiation to the more quiescent myofibroblasts (Section 3.2). It will also be important to target these cells before harmful collagen deposition occurs. The best timepoint would need to be optimised. The use of polycistronic vectors improves delivery efficiency and also allows manipulation of the relative levels of each factor, which also appears to be an important consideration [88].

Cardiac fibroblasts perform an important role in the heart and therefore we must ensure that only harmful scar tissue is reprogrammed. How can we target reprogramming to specific cell populations to prevent harmful off-target effects? Perhaps the answer to this may lie in engineering vectors to drive expression using enhancers/promoters active only in activated myofibroblasts, or by building in negative selection, which shuts down the expression of reprogramming factors if present in an unwanted cell type. Viruses could be targeted to specific cell types by engineering surface epitopes.

Safety is a concern with any viral vector due to the danger of oncogenic insertional mutagenesis and this has been an impediment in the clinical application of this technology. Qian's highly efficient method $[107,108]$ nevertheless depends on the use of integrating viruses, which may be unsafe for clinical use, and development of a non-integrating approach is needed. To this end, results from Ieda's lab in mice using the non-integrating Sendai virus are promising, and fortuitously this method also appears to improve reprogramming efficiency [113].

An alternative approach to improve safety may be to eliminate the viral vector entirely and to find alternative methods. Small molecule drugs can modify epigenetic status [109]. Chang et al. have demonstrated the successful delivery of GMT using gold nanoparticles coated with an arginine-rich peptide in a mouse model of MI [116]. However, these are non-specific methods that do not specifically target activated myofibroblasts and may result in harmful alterations to other cells in the heart. In addition, small molecule epigenetic modifiers may modify off-target gene loci.

A modification of CRISPR gene editing may provide a method to specifically modify the epigenetic status of endogenous genes required for reprogramming. A modified enzymatically inactive version of CAS9, known as dead CAS9 (dCAS9) can be targeted using short guide RNAs to enhancers of transcription factors such as the GMHT network [114]. The guide RNA contains aptamers that recruit transcriptional activators to the locus, while CAS9 itself can be engineered to contain an activation domain [121]. This method has the advantage of activating endogenous genes rather than driving transgene expression and is also more easily adaptable to target different genes in the cardiogenic network. However, 
expression of dCAS9 in the original protocol required viral transduction and an alternative non-viral delivery method needs to be developed.

miRNA has been shown to be effective in reprogramming [106]. Although in vivo work to date has used a viral vector to drive miRNA expression, it is possible to deliver miRNA to cells without the use of a virus. For example, miRNAs are known to be transferred between cells by extracellular vesicles and these can be harnessed as novel therapeutics [122]. miRNA or synthetic mimics can be loaded into vesicles produced in vitro and these could in theory be targeted to specific populations of cells within the injured heart by engineering of transmembrane proteins [123]. Such an approach may also be useful for delivery of drugs or mRNA.

Despite these hurdles that remain to be fully overcome the field offers much hope that one day a patient arriving at an intensive cardiac unit following an acute myocardial infarction may receive a simple injection as part of their treatment and this might serve to regenerate the myocardium, preventing fibrosis and restoring cardiac function.

Author Contributions: Conceptualization, I.M.D.; writing-original draft preparation, E.A., R.M., A.J., K.F. and I.M.D.; writing-review and editing, I.M.D.; supervision, I.M.D.; project administration, I.M.D. All authors have read and agreed to the published version of the manuscript.

Funding: This research received no external funding.

Institutional Review Board Statement: Not applicable.

Informed Consent Statement: Not applicable.

Data Availability Statement: Not applicable.

Conflicts of Interest: The authors declare no conflict of interest.

\section{References}

1. Sulo, G.; Igland, J.; Vollset, S.E.; Nygård, O.; Ebbing, M.; Sulo, E.; Egeland, G.M.; Tell, G.S. Heart failure complicating acute myocardial infarction; burden and timing of occurrence: A nation-wide analysis including 86,771 patients from the Cardiovascular Disease in Norway (CVDNOR) Project. J. Am. Heart Assoc. 2016, 5, e002667. [CrossRef] [PubMed]

2. Hung, J.; Teng, T.H.K.; Finn, J.; Knuiman, M.; Briffa, T.; Stewart, S.; Sanfilippo, F.M.; Ridout, S.; Hobbs, M. Trends From 1996 to 2007 in Incidence and Mortality Outcomes of Heart Failure After Acute Myocardial Infarction: A Population-Based Study of 20,812 Patients With First Acute Myocardial Infarction in W estern Australia. J. Am. Heart Assoc. 2013, 2, e000172. [CrossRef] [PubMed]

3. Jenča, D.; Melenovský, V.; Stehlik, J.; Staněk, V.; Kettner, J.; Kautzner, J.; Adámková, V.; Wohlfahrt, P. Heart failure after myocardial infarction: Incidence and predictors. ESC Heart Fail. 2021, 8, 222-237. [CrossRef]

4. Takahashi, K.; Yamanaka, S. Induction of pluripotent stem cells from mouse embryonic and adult fibroblast cultures by defined factors. Cell 2006, 126, 663-676. [CrossRef]

5. Wang, H.; Yang, Y.; Liu, J.; Qian, L. Direct cell reprogramming: Approaches, mechanisms and progress. Nat. Rev. Mol. Cell Biol. 2021, 22, 410-424. [CrossRef]

6. Werner, J.H.; Rosenberg, J.H.; Um, J.Y.; Moulton, M.J.; Agrawal, D.K. Molecular discoveries and treatment strategies by direct reprogramming in cardiac regeneration. Transl. Res. 2019, 203, 73-87. [CrossRef]

7. Kurotsu, S.; Suzuki, T.; Ieda, M. Direct reprogramming, epigenetics, and cardiac regeneration. J. Card. Fail. 2017, $23,552-557$. [CrossRef]

8. Tucker, N.R.; Chaffin, M.; Fleming, S.J.; Hall, A.W.; Parsons, V.A.; Bedi, K.C.; Akkad, A.-D.; Herndon, C.N.; Arduini, A.; Papangeli, I.; et al. Transcriptional and Cellular Diversity of the Human Heart. Circulation 2020, 142, 466-482. [CrossRef] [PubMed]

9. Dykes, I.M.; van Bueren, K.L.; Scambler, P.J. HIC2 regulates isoform switching during maturation of the cardiovascular system. J. Mol. Cell. Cardiol. 2018, 114, 29-37. [CrossRef] [PubMed]

10. Yin, Z.; Ren, J.; Guo, W. Sarcomeric protein isoform transitions in cardiac muscle: A journey to heart failure. Biochim. Biophys. Acta 2015, 1852, 47-52. [CrossRef]

11. England, J.; Loughna, S. Heavy and light roles: Myosin in the morphogenesis of the heart. Cell. Mol. Life Sci. CMLS 2013, 70, 1221-1239. [CrossRef] [PubMed]

12. Paik, D.T.; Cho, S.; Tian, L.; Chang, H.Y.; Wu, J.C. Single-Cell RNA sequencing in cardiovascular development, disease and medicine. Nat. Rev. Cardiol. 2020, 17, 457-473. [CrossRef]

13. Ackers-Johnson, M.; Tan, W.L.W.; Foo, R.S.-Y. Following hearts, one cell at a time: Recent applications of single-cell RNA sequencing to the understanding of heart disease. Nat. Commun. 2018, 9, 4434. [CrossRef]

14. Zhou, P.; Pu, W.T. Recounting Cardiac Cellular Composition. Circ. Res. 2016, 118, 368-370. [CrossRef] 
15. Weber, K.T.; Sun, Y.; Bhattacharya, S.K.; Ahokas, R.A.; Gerling, I.C. Myofibroblast-mediated mechanisms of pathological remodelling of the heart. Nat. Rev. Cardiol. 2013, 10, 15. [CrossRef]

16. Tallquist, M.D.; Molkentin, J.D. Redefining the identity of cardiac fibroblasts. Nat. Rev. Cardiol. 2017, 14, 484-491. [CrossRef]

17. Furtado, M.B.; Costa, M.W.; Pranoto, E.A.; Salimova, E.; Pinto, A.R.; Lam, N.T.; Park, A.; Snider, P.; Chandran, A.; Harvey, R.P. Cardiogenic genes expressed in cardiac fibroblasts contribute to heart development and repair. Circ. Res. 2014, 114, 1422-1434. [CrossRef] [PubMed]

18. Swirski, F.K.; Nahrendorf, M. Cardioimmunology: The immune system in cardiac homeostasis and disease. Nat. Rev. Immunol. 2018, 18, 733-744. [CrossRef] [PubMed]

19. Greenberg, M.V.; Bourc'his, D. The diverse roles of DNA methylation in mammalian development and disease. Nat. Rev. Mol. Cell Biol. 2019, 20, 590-607. [CrossRef] [PubMed]

20. Klemm, S.L.; Shipony, Z.; Greenleaf, W.J. Chromatin accessibility and the regulatory epigenome. Nat. Rev. Genet. 2019, 20, 207-220. [CrossRef]

21. Prummel, K.D.; Nieuwenhuize, S.; Mosimann, C. The lateral plate mesoderm. Development 2020, 147, dev175059. [CrossRef]

22. Chabab, S.; Lescroart, F.; Rulands, S.; Mathiah, N.; Simons, B.D.; Blanpain, C. Uncovering the Number and Clonal Dynamics of Mesp1 Progenitors during Heart Morphogenesis. Cell Rep. 2016, 14, 1-10. [CrossRef] [PubMed]

23. Chan, S.S.; Shi, X.; Toyama, A.; Arpke, R.W.; Dandapat, A.; Iacovino, M.; Kang, J.; Le, G.; Hagen, H.R.; Garry, D.J.; et al. Mesp1 patterns mesoderm into cardiac, hematopoietic, or skeletal myogenic progenitors in a context-dependent manner. Cell Stem Cell 2013, 12, 587-601. [CrossRef] [PubMed]

24. Soibam, B.; Benham, A.; Kim, J.; Weng, K.-C.; Yang, L.; Xu, X.; Robertson, M.; Azares, A.; Cooney, A.J.; Schwartz, R.J.; et al. Genome-Wide Identification of MESP1 Targets Demonstrates Primary Regulation Over Mesendoderm Gene Activity. Stem Cells 2015, 33, 3254-3265. [CrossRef]

25. Bondue, A.; Lapouge, G.; Paulissen, C.; Semeraro, C.; Iacovino, M.; Kyba, M.; Blanpain, C. Mesp1 Acts as a Master Regulator of Multipotent Cardiovascular Progenitor Specification. Cell Stem Cell 2008, 3, 69-84. [CrossRef]

26. Saga, Y.; Miyagawa-Tomita, S.; Takagi, A.; Kitajima, S.; Miyazaki, J.; Inoue, T. MesP1 is expressed in the heart precursor cells and required for the formation of a single heart tube. Development 1999, 126, 3437-3447. [CrossRef]

27. Islas, J.F.; Liu, Y.; Weng, K.C.; Robertson, M.J.; Zhang, S.; Prejusa, A.; Harger, J.; Tikhomirova, D.; Chopra, M.; Iyer, D.; et al. Transcription factors ETS2 and MESP1 transdifferentiate human dermal fibroblasts into cardiac progenitors. Proc. Natl. Acad. Sci. USA 2012, 109, 13016-13021. [CrossRef]

28. Olson, E.N. Gene Regulatory Networks in the Evolution and Development of the Heart. Science 2006, 313, 1922-1927. [CrossRef] [PubMed]

29. Bruneau, B.G. Signaling and transcriptional networks in heart development and regeneration. Cold Spring Harb. Perspect. Biol. 2013, 5, a008292. [CrossRef]

30. Hiroi, Y.; Kudoh, S.; Monzen, K.; Ikeda, Y.; Yazaki, Y.; Nagai, R.; Komuro, I. Tbx5 associates with Nkx2-5 and synergistically promotes cardiomyocyte differentiation. Nat. Genet. 2001, 28, 276-280. [CrossRef] [PubMed]

31. Durocher, D.; Charron, F.; Warren, R.; Schwartz, R.J.; Nemer, M. The cardiac transcription factors Nkx2-5 and GATA-4 are mutual cofactors. EMBO J. 1997, 16, 5687-5696. [CrossRef]

32. Lescroart, F.; Chabab, S.; Lin, X.; Rulands, S.; Paulissen, C.; Rodolosse, A.; Auer, H.; Achouri, Y.; Dubois, C.; Bondue, A. Early lineage restriction in temporally distinct populations of Mesp1 progenitors during mammalian heart development. Nat. Cell Biol. 2014, 16, 829. [CrossRef]

33. Moses, K.A.; DeMayo, F.; Braun, R.M.; Reecy, J.L.; Schwartz, R.J. Embryonic expression of an Nkx2-5/Cre gene using ROSA26 reporter mice. Genesis 2001, 31, 176-180. [CrossRef] [PubMed]

34. Molkentin, J.D.; Lin, Q.; Duncan, S.A.; Olson, E.N. Requirement of the transcription factor GATA4 for heart tube formation and ventral morphogenesis. Genes Dev. 1997, 11, 1061-1072. [CrossRef]

35. Bruneau, B.G.; Nemer, G.; Schmitt, J.P.; Charron, F.; Robitaille, L.; Caron, S.; Conner, D.A.; Gessler, M.; Nemer, M.; Seidman, C.E. A murine model of Holt-Oram syndrome defines roles of the T-box transcription factor Tbx 5 in cardiogenesis and disease. Cell 2001, 106, 709-721. [CrossRef]

36. Lin, Q.; Schwarz, J.; Bucana, C.; Olson, E.N. Control of mouse cardiac morphogenesis and myogenesis by transcription factor MEF2C. Science 1997, 276, 1404-1407. [CrossRef]

37. Cai, C.L.; Liang, X.; Shi, Y.; Chu, P.H.; Pfaff, S.L.; Chen, J.; Evans, S. Isl1 identifies a cardiac progenitor population that proliferates prior to differentiation and contributes a majority of cells to the heart. Dev. Cell 2003, 5, 877-889. [CrossRef]

38. Ma, Q.; Zhou, B.; Pu, W.T. Reassessment of Isl1 and Nkx2-5 cardiac fate maps using a Gata4-based reporter of Cre activity. Dev. Biol. 2008, 323, 98-104. [CrossRef] [PubMed]

39. Dodou, E.; Verzi, M.P.; Anderson, J.P.; Xu, S.-M.; Black, B.L. Mef2c is a direct transcriptional target of ISL1 and GATA factors in the anterior heart field during mouse embryonic development. Development 2004, 131, 3931-3942. [CrossRef]

40. Miano, J.M. Myocardin in biology and disease. J. Biomed. Res. 2015, 29, 3-19.

41. Wystub, K.; Besser, J.; Bachmann, A.; Boettger, T.; Braun, T. miR-1/133a Clusters Cooperatively Specify the Cardiomyogenic Lineage by Adjustment of Myocardin Levels during Embryonic Heart Development. PLoS Genet. 2013, 9, e1003793. [CrossRef] [PubMed] 
42. Furtado, M.B.; Nim, H.T.; Boyd, S.E.; Rosenthal, N.A. View from the heart: Cardiac fibroblasts in development, scarring and regeneration. Development 2016, 143, 387-397. [CrossRef]

43. Moore-Morris, T.; Guimarães-Camboa, N.; Banerjee, I.; Zambon, A.C.; Kisseleva, T.; Velayoudon, A.; Stallcup, W.B.; Gu, Y.; Dalton, N.D.; Cedenilla, M. Resident fibroblast lineages mediate pressure overload-induced cardiac fibrosis. J. Clin. Investig. 2014, 124, 2921-2934. [CrossRef] [PubMed]

44. Ali, S.R.; Ranjbarvaziri, S.; Talkhabi, M.; Zhao, P.; Subat, A.; Hojjat, A.; Kamran, P.; Müller, A.M.; Volz, K.S.; Tang, Z. Developmental heterogeneity of cardiac fibroblasts does not predict pathological proliferation and activation. Circ. Res. 2014, 115, 625-635. [CrossRef]

45. Simões, F.C.; Riley, P.R. The ontogeny, activation and function of the epicardium during heart development and regeneration. Development 2018, 145, dev155994. [CrossRef]

46. Dyer, L.A.; Patterson, C. Development of the endothelium: An emphasis on heterogeneity. Semin. Thromb. Hemost. 2010, 36, 227-235. [CrossRef]

47. Qiu, J.; Hirschi, K.K. Endothelial Cell Development and Its Application to Regenerative Medicine. Circ. Res. 2019, 125, 489-501. [CrossRef] [PubMed]

48. Yamagishi, H. Cardiac Neural Crest. Cold Spring Harb. Perspect. Biol. 2005, 16, 704-715. [CrossRef] [PubMed]

49. Konstantinidis, K.; Whelan, R.S.; Kitsis, R.N. Mechanisms of cell death in heart disease. Arter. Thromb. Vasc. Biol. 2012, 32, 1552-1562. [CrossRef] [PubMed]

50. Gwechenberger, M.; Mendoza, L.H.; Youker, K.A.; Frangogiannis, N.G.; Smith, C.W.; Michael, L.H.; Entman, M.L. Cardiac myocytes produce interleukin-6 in culture and in viable border zone of reperfused infarctions. Circulation 1999, 99, 546-551. [CrossRef]

51. Frangogiannis, N.G. Chemokines in the ischemic myocardium: From inflammation to fibrosis. Inflamm. Res. 2004, 53, 585-595. [CrossRef]

52. Hanna, A.; Frangogiannis, N.G. The Role of the TGF- $\beta$ Superfamily in Myocardial Infarction. Front. Cardiovasc. Med. 2019, 6, 140. [CrossRef] [PubMed]

53. Poss, K.D.; Wilson, L.G.; Keating, M.T. Heart regeneration in zebrafish. Science 2002, 298, 2188-2190. [CrossRef] [PubMed]

54. Sanz-Morejón, A.; Mercader, N. Recent insights into zebrafish cardiac regeneration. Curr. Opin. Genet. Dev. 2020, 64, 37-43. [CrossRef]

55. Porrello, E.R.; Olson, E.N. A neonatal blueprint for cardiac regeneration. Stem Cell Res. 2014, 13, 556-570. [CrossRef] [PubMed]

56. Wynn, T. Cellular and molecular mechanisms of fibrosis. J. Pathol. 2008, 214, 199-210. [CrossRef] [PubMed]

57. Haudek, S.B.; Xia, Y.; Huebener, P.; Lee, J.M.; Carlson, S.; Crawford, J.R.; Pilling, D.; Gomer, R.H.; Trial, J.; Frangogiannis, N.G. Bone marrow-derived fibroblast precursors mediate ischemic cardiomyopathy in mice. Proc. Natl. Acad. Sci. USA 2006, 103, 18284-18289. [CrossRef]

58. Van Amerongen, M.; Bou-Gharios, G.; Popa, E.; van Ark, J.; Petersen, A.; van Dam, G.; van Luyn, M.; Harmsen, M. Bone marrow-derived myofibroblasts contribute functionally to scar formation after myocardial infarction. J. Pathol. 2008, 214, 377-386. [CrossRef]

59. Desmoulière, A.; Geinoz, A.; Gabbiani, F.; Gabbiani, G. Transforming growth factor-beta 1 induces alpha-smooth muscle actin expression in granulation tissue myofibroblasts and in quiescent and growing cultured fibroblasts. J. Cell Biol. 1993, 122, 103-111. [CrossRef]

60. Davis, J.; Molkentin, J.D. Myofibroblasts: Trust your heart and let fate decide. J. Mol. Cell. Cardiol. 2014, 70, 9-18. [CrossRef]

61. Tomasek, J.J.; Gabbiani, G.; Hinz, B.; Chaponnier, C.; Brown, R.A. Myofibroblasts and mechano-regulation of connective tissue remodelling. Nat. Rev. Mol. Cell Biol. 2002, 3, 349-363. [CrossRef]

62. Shinde, A.; Frangogiannis, N. Fibroblasts in myocardial infarction: A role in inflammation and repair. J. Mol. Cell. Cardiol. 2014, 70, 74-82. [CrossRef]

63. Simões, F.C.; Cahill, T.J.; Kenyon, A.; Gavriouchkina, D.; Vieira, J.M.; Sun, X.; Pezzolla, D.; Ravaud, C.; Masmanian, E.; Weinberger, M.; et al. Macrophages directly contribute collagen to scar formation during zebrafish heart regeneration and mouse heart repair. Nat. Commun. 2020, 11, 600. [CrossRef] [PubMed]

64. Piek, A.; de Boer, R.A.; Silljé, H.H.W. The fibrosis-cell death axis in heart failure. Heart Fail. Rev. 2016, 21, 199-211. [CrossRef] [PubMed]

65. Gabriel-Costa, D. The pathophysiology of myocardial infarction-induced heart failure. Pathophysiology 2018, 25, 277-284. [CrossRef] [PubMed]

66. Cleland, J.; Torabi, A.; Khan, N. Epidemiology and management of heart failure and left ventricular systolic dysfunction in the aftermath of a myocardial infarction. Heart 2005, 91 (Suppl. S2), ii7-ii13. [CrossRef]

67. Li, M.; Belmonte, J.C.I. Ground rules of the pluripotency gene regulatory network. Nat. Rev. Genet. 2017, 18, 180-191. [CrossRef]

68. Kinoshita, M.; Smith, A. Pluripotency Deconstructed. Dev. Growth Differ. 2018, 60, 44-52. [CrossRef]

69. Waddington, C.H. The Strategy of the Genes; Routledge: Oxfordshire, UK, 1957.

70. Takahashi, K.; Tanabe, K.; Ohnuki, M.; Narita, M.; Ichisaka, T.; Tomoda, K.; Yamanaka, S. Induction of pluripotent stem cells from adult human fibroblasts by defined factors. Cell 2007, 131, 861-872. [CrossRef]

71. Yu, J.; Vodyanik, M.A.; Smuga-Otto, K.; Antosiewicz-Bourget, J.; Frane, J.L.; Tian, S.; Nie, J.; Jonsdottir, G.A.; Ruotti, V.; Stewart, R.; et al. Induced pluripotent stem cell lines derived from human somatic cells. Science 2007, 318, 1917-1920. [CrossRef] 
72. Tsialikas, J.; Romer-Seibert, J. LIN28: Roles and regulation in development and beyond. Development 2015, 142, 2397-2404. [CrossRef]

73. Okita, K.; Matsumura, Y.; Sato, Y.; Okada, A.; Morizane, A.; Okamoto, S.; Hong, H.; Nakagawa, M.; Tanabe, K.; Tezuka, K.-I. A more efficient method to generate integration-free human iPS cells. Nat. Methods 2011, 8, 409-412. [CrossRef]

74. Yu, J.; Hu, K.; Smuga-Otto, K.; Tian, S.; Stewart, R.; Slukvin, I.I.; Thomson, J.A. Human induced pluripotent stem cells free of vector and transgene sequences. Science 2009, 324, 797-801. [CrossRef]

75. Warren, L.; Manos, P.D.; Ahfeldt, T.; Loh, Y.-H.; Li, H.; Lau, F.; Ebina, W.; Mandal, P.K.; Smith, Z.D.; Meissner, A. Highly efficient reprogramming to pluripotency and directed differentiation of human cells with synthetic modified mRNA. Cell Stem Cell 2010, 7, 618-630. [CrossRef] [PubMed]

76. Hou, P.; Li, Y.; Zhang, X.; Liu, C.; Guan, J.; Li, H.; Zhao, T.; Ye, J.; Yang, W.; Liu, K. Pluripotent stem cells induced from mouse somatic cells by small-molecule compounds. Science 2013, 341, 651-654. [CrossRef]

77. Yang, L.; Soonpaa, M.H.; Adler, E.D.; Roepke, T.K.; Kattman, S.J.; Kennedy, M.; Henckaerts, E.; Bonham, K.; Abbott, G.W.; Linden, R.M.; et al. Human cardiovascular progenitor cells develop from a KDR+ embryonic-stem-cell-derived population. Nature 2008, 453, 524-528. [CrossRef]

78. Avolio, E.; Caputo, M.; Madeddu, P. Stem cell therapy and tissue engineering for correction of congenital heart disease. Front. Cell Dev. Biol. 2015, 3, 39. [CrossRef] [PubMed]

79. Wang, Q.; Yang, H.; Bai, A.; Jiang, W.; Li, X.; Wang, X.; Mao, Y.; Lu, C.; Qian, R.; Guo, F. Functional engineered human cardiac patches prepared from nature's platform improve heart function after acute myocardial infarction. Biomaterials 2016, 105, 52-65. [CrossRef] [PubMed]

80. Su, T.; Huang, K.; Daniele, M.A.; Hensley, M.T.; Young, A.T.; Tang, J.; Allen, T.A.; Vandergriff, A.C.; Erb, P.D.; Ligler, F.S. Cardiac stem cell patch integrated with microengineered blood vessels promotes cardiomyocyte proliferation and neovascularization after acute myocardial infarction. ACS Appl. Mater. Interfaces 2018, 10, 33088-33096. [CrossRef]

81. Ieda, M.; Fu, J.D.; Delgado-Olguin, P.; Vedantham, V.; Hayashi, Y.; Bruneau, B.G.; Srivastava, D. Direct reprogramming of fibroblasts into functional cardiomyocytes by defined factors. Cell 2010, 142, 375-386. [CrossRef]

82. Franco, D.; Lamers, W.H.; Moorman, A.F.M. Patterns of expression in the developing myocardium: Towards a morphologically integrated transcriptional model. Cardiovasc. Res. 1998, 38, 25-53. [CrossRef]

83. Wessels, A.; Vermeulen, J.; Virágh, S.; Kalman, F.; Lamers, W.; Moorman, A. Spatial distribution of "tissue-specific" antigens in the developing human heart and skeletal muscle. II. An immunohistochemical analysis of myosin heavy chain isoform expression patterns in the embryonic heart. Anat. Rec. 1991, 229, 355-368. [CrossRef] [PubMed]

84. Lyons, G.E.; Schiaffino, S.; Sassoon, D.; Barton, P.; Buckingham, M. Developmental regulation of myosin gene expression in mouse cardiac muscle. J. Cell Biol. 1990, 111 Pt 1, 2427-2436. [CrossRef]

85. Xie, L.; Hoffmann, A.D.; Burnicka-Turek, O.; Friedland-Little, J.M.; Zhang, K.; Moskowitz, I.P. Tbx5-hedgehog molecular networks are essential in the second heart field for atrial septation. Dev. Cell 2012, 23, 280-291. [CrossRef]

86. Stone, N.R.; Gifford, C.A.; Thomas, R.; Pratt, K.J.B.; Samse-Knapp, K.; Mohamed, T.M.A.; Radzinsky, E.M.; Schricker, A.; Ye, L.; Yu, P.; et al. Context-Specific Transcription Factor Functions Regulate Epigenomic and Transcriptional Dynamics during Cardiac Reprogramming. Cell Stem Cell 2019, 25, 87-102.e9. [CrossRef] [PubMed]

87. Hashimoto, H.; Wang, Z.; Garry, G.A.; Malladi, V.S.; Botten, G.A.; Ye, W.; Zhou, H.; Osterwalder, M.; Dickel, D.E.; Visel, A.; et al. Cardiac Reprogramming Factors Synergistically Activate Genome-wide Cardiogenic Stage-Specific Enhancers. Cell Stem Cell 2019, 25, 69-86.e5. [CrossRef] [PubMed]

88. Wang, L.; Liu, Z.; Yin, C.; Asfour, H.; Chen, O.; Li, Y.; Bursac, N.; Liu, J.; Qian, L. Stoichiometry of Gata4, Mef2c, and Tbx5 Influences the Efficiency and Quality of Induced Cardiac Myocyte Reprogramming. Circ. Res. 2015, 116, 237-244. [CrossRef] [PubMed]

89. Ghosh, T.K.; Song, F.F.; Packham, E.A.; Buxton, S.; Robinson, T.E.; Ronksley, J.; Self, T.; Bonser, A.J.; Brook, J.D. Physical interaction between TBX5 and MEF2C is required for early heart development. Mol. Cell. Biol. 2009, 29, 2205-2218. [CrossRef] [PubMed]

90. Song, K.; Nam, Y.J.; Luo, X.; Qi, X.; Tan, W.; Huang, G.N.; Acharya, A.; Smith, C.L.; Tallquist, M.D.; Neilson, E.G.; et al. Heart repair by reprogramming non-myocytes with cardiac transcription factors. Nature 2012, 485, 599-604. [CrossRef]

91. Abad, M.; Hashimoto, H.; Zhou, H.; Morales, M.G.; Chen, B.; Bassel-Duby, R.; Olson, E.N. Notch inhibition enhances cardiac reprogramming by increasing MEF2C transcriptional activity. Stem Cell Rep. 2017, 8, 548-560. [CrossRef]

92. Zhou, H.; Dickson, M.E.; Kim, M.S.; Bassel-Duby, R.; Olson, E.N. Akt1/protein kinase B enhances transcriptional reprogramming of fibroblasts to functional cardiomyocytes. Proc. Natl. Acad. Sci. USA 2015, 112, 11864-11869. [CrossRef]

93. Zhou, H.; Morales, M.G.; Hashimoto, H.; Dickson, M.E.; Song, K.; Ye, W.; Kim, M.S.; Niederstrasser, H.; Wang, Z.; Chen, B. ZNF281 enhances cardiac reprogramming by modulating cardiac and inflammatory gene expression. Genes Dev. 2017, 31, 1770-1783. [CrossRef]

94. Zhao, Y.; Londono, P.; Cao, Y.; Sharpe, E.J.; Proenza, C.; O’Rourke, R.; Jones, K.L.; Jeong, M.Y.; Walker, L.A.; Buttrick, P.M. High-Efficiency reprogramming of fibroblasts into cardiomyocytes requires suppression of pro-fibrotic signalling. Nat. Commun. 2015, 6, 8243. [CrossRef] [PubMed]

95. Addis, R.C.; Ifkovits, J.L.; Pinto, F.; Kellam, L.D.; Esteso, P.; Rentschler, S.; Christoforou, N.; Epstein, J.A.; Gearhart, J.D. Optimization of direct fibroblast reprogramming to cardiomyocytes using calcium activity as a functional measure of success. $J$. Mol. Cell. Cardiol. 2013, 60, 97-106. [CrossRef] [PubMed] 
96. Ifkovits, J.L.; Addis, R.C.; Epstein, J.A.; Gearhart, J.D. Inhibition of TGF $\beta$ signaling increases direct conversion of fibroblasts to induced cardiomyocytes. PLoS ONE 2014, 9, e89678. [CrossRef] [PubMed]

97. Protze, S.; Khattak, S.; Poulet, C.; Lindemann, D.; Tanaka, E.M.; Ravens, U. A new approach to transcription factor screening for reprogramming of fibroblasts to cardiomyocyte-like cells. J. Mol. Cell. Cardiol. 2012, 53, 323-332. [CrossRef] [PubMed]

98. Qian, L.; Huang, Y.; Spencer, C.I.; Foley, A.; Vedantham, V.; Liu, L.; Conway, S.J.; Fu, J.-D.; Srivastava, D. In vivo reprogramming of murine cardiac fibroblasts into induced cardiomyocytes. Nature 2012, 485, 593-598. [CrossRef]

99. Fu, J.D.; Stone, N.R.; Liu, L.; Spencer, C.I.; Qian, L.; Hayashi, Y.; Delgado-Olguin, P.; Ding, S.; Bruneau, B.G.; Srivastava, D. Direct reprogramming of human fibroblasts toward a cardiomyocyte-like state. Stem Cell Rep. 2013, 1, 235-247. [CrossRef]

100. Mohamed, T.M.; Stone, N.R.; Berry, E.C.; Radzinsky, E.; Huang, Y.; Pratt, K.; Ang, Y.-S.; Yu, P.; Wang, H.; Tang, S. Chemical enhancement of in vitro and in vivo direct cardiac reprogramming. Circulation 2017, 135, 978-995. [CrossRef]

101. Nam, Y.J.; Song, K.; Luo, X.; Daniel, E.; Lambeth, K.; West, K.; Hill, J.A.; DiMaio, J.M.; Baker, L.A.; Bassel-Duby, R.; et al. Reprogramming of human fibroblasts toward a cardiac fate. Proc. Natl. Acad. Sci. USA 2013, 110, 5588-5593. [CrossRef]

102. Inagawa, K.; Miyamoto, K.; Yamakawa, H.; Muraoka, N.; Sadahiro, T.; Umei, T.; Wada, R.; Katsumata, Y.; Kaneda, R.; Nakade, K.; et al. Induction of cardiomyocyte-like cells in infarct hearts by gene transfer of Gata4, Mef2c, and Tbx5. Circ. Res. 2012, 111, 1147-1156. [CrossRef]

103. Wada, R.; Muraoka, N.; Inagawa, K.; Yamakawa, H.; Miyamoto, K.; Sadahiro, T.; Umei, T.; Kaneda, R.; Suzuki, T.; Kamiya, K.; et al. Induction of human cardiomyocyte-like cells from fibroblasts by defined factors. Proc. Natl. Acad. Sci. USA 2013, 110, 12667-12672. [CrossRef]

104. Muraoka, N.; Yamakawa, H.; Miyamoto, K.; Sadahiro, T.; Umei, T.; Isomi, M.; Nakashima, H.; Akiyama, M.; Wada, R.; Inagawa, $\mathrm{K} . ;$ et al. MiR-133 promotes cardiac reprogramming by directly repressing Snai1 and silencing fibroblast signatures. $E M B O J$. 2014, 33, 1565-1581. [CrossRef] [PubMed]

105. Yamakawa, H.; Muraoka, N.; Miyamoto, K.; Sadahiro, T.; Isomi, M.; Haginiwa, S.; Kojima, H.; Umei, T.; Akiyama, M.; Kuishi, Y.; et al. Fibroblast Growth Factors and Vascular Endothelial Growth Factor Promote Cardiac Reprogramming under Defined Conditions. Stem Cell Rep. 2015, 5, 1128-1142. [CrossRef] [PubMed]

106. Jayawardena, T.M.; Egemnazarov, B.; Finch, E.A.; Zhang, L.; Payne, J.A.; Pandya, K.; Zhang, Z.; Rosenberg, P.; Mirotsou, M.; Dzau, V.J. MicroRNA-mediated in vitro and in vivo direct reprogramming of cardiac fibroblasts to cardiomyocytes. Circ. Res. 2012, 110, 1465-1473. [CrossRef] [PubMed]

107. Garbutt, T.A.; Zhou, Y.; Keepers, B.; Liu, J.; Qian, L. An Optimized Protocol for Human Direct Cardiac Reprogramming. STAR Protoc. 2020, 1, 100010. [CrossRef]

108. Zhou, Y.; Liu, Z.; Welch, J.D.; Gao, X.; Wang, L.; Garbutt, T.; Keepers, B.; Ma, H.; Prins, J.F.; Shen, W.; et al. Single-Cell Transcriptomic Analyses of Cell Fate Transitions during Human Cardiac Reprogramming. Cell Stem Cell 2019, 25, 149-164.e9. [CrossRef]

109. Fu, Y.; Huang, C.; Xu, X.; Gu, H.; Ye, Y.; Jiang, C.; Qiu, Z.; Xie, X. Direct reprogramming of mouse fibroblasts into cardiomyocytes with chemical cocktails. Cell Res. 2015, 25, 1013-1024. [CrossRef]

110. Lalit, P.A.; Salick, M.R.; Nelson, D.O.; Squirrell, J.M.; Shafer, C.M.; Patel, N.G.; Saeed, I.; Schmuck, E.G.; Markandeya, Y.S.; Wong, R. Lineage reprogramming of fibroblasts into proliferative induced cardiac progenitor cells by defined factors. Cell Stem Cell 2016, 18, 354-367. [CrossRef]

111. Christoforou, N.; Chakraborty, S.; Kirkton, R.D.; Adler, A.F.; Addis, R.C.; Leong, K.W. Core Transcription Factors, MicroRNAs, and Small Molecules Drive Transdifferentiation of Human Fibroblasts Towards The Cardiac Cell Lineage. Sci. Rep. 2017, 7, 40285. [CrossRef]

112. Chen, J.X.; Krane, M.; Deutsch, M.A.; Wang, L.; Rav-Acha, M.; Gregoire, S.; Engels, M.C.; Rajarajan, K.; Karra, R.; Abel, E.D.; et al. Inefficient reprogramming of fibroblasts into cardiomyocytes using Gata4, Mef2c, and Tbx5. Circ. Res. 2012, 111, 50-55. [CrossRef] [PubMed]

113. Miyamoto, K.; Akiyama, M.; Tamura, F.; Isomi, M.; Yamakawa, H.; Sadahiro, T.; Muraoka, N.; Kojima, H.; Haginiwa, S.; Kurotsu, S.; et al. Direct In Vivo Reprogramming with Sendai Virus Vectors Improves Cardiac Function after Myocardial Infarction. Cell Stem Cell 2018, 22, 91-103.e5. [CrossRef] [PubMed]

114. Wang, J.; Jiang, X.; Zhao, L.; Zuo, S.; Chen, X.; Zhang, L.; Lin, Z.; Zhao, X.; Qin, Y.; Zhou, X. Lineage reprogramming of fibroblasts into induced cardiac progenitor cells by CRISPR/Cas9-based transcriptional activators. Acta Pharm. Sin. B 2020, 10, 313-326. [CrossRef] [PubMed]

115. Jayawardena, T.M.; Finch, E.A.; Zhang, L.; Zhang, H.; Hodgkinson, C.P.; Pratt, R.E.; Rosenberg, P.B.; Mirotsou, M.; Dzau, V.J. MicroRNA induced cardiac reprogramming in vivo: Evidence for mature cardiac myocytes and improved cardiac function. Circ. Res. 2015, 116, 418-424. [CrossRef] [PubMed]

116. Chang, Y.; Lee, E.; Kim, J.; Kwon, Y.-W.; Kwon, Y.; Kim, J. Efficient in vivo direct conversion of fibroblasts into cardiomyocytes using a nanoparticle-based gene carrier. Biomaterials 2019, 192, 500-509. [CrossRef]

117. Ieda, M. Key Regulators of Cardiovascular Differentiation and Regeneration: Harnessing the Potential of Direct Reprogramming to Treat Heart Failure. J. Card. Fail. 2020, 26, 80-84. [CrossRef]

118. Chen, O.; Qian, L. Direct Cardiac Reprogramming: Advances in Cardiac Regeneration. BioMed. Res. Int. 2015, $2015,580406$. [CrossRef] 
119. Chen, J.X.; Plonowska, K.; Wu, S.M. Somatic Cell Reprogramming into Cardiovascular Lineages. J. Cardiovasc. Pharmacol. Ther. 2014, 19, 340-349. [CrossRef]

120. Tani, H.; Sadahiro, T.; Ieda, M. Direct Cardiac Reprogramming: A Novel Approach for Heart Regeneration. Int. J. Mol. Sci. 2018, 19, 2629. [CrossRef]

121. Konermann, S.; Brigham, M.D.; Trevino, A.E.; Joung, J.; Abudayyeh, O.O.; Barcena, C.; Hsu, P.D.; Habib, N.; Gootenberg, J.S.; Nishimasu, H.; et al. Genome-Scale transcriptional activation by an engineered CRISPR-Cas9 complex. Nature 2015, 517, 583-588. [CrossRef]

122. Dykes, I.M. Exosomes in Cardiovascular Medicine. Cardiol. Ther. 2017, 6, 225-237. [CrossRef] [PubMed]

123. Murphy, D.E.; de Jong, O.G.; Brouwer, M.; Wood, M.J.; Lavieu, G.; Schiffelers, R.M.; Vader, P. Extracellular vesicle-based therapeutics: Natural versus engineered targeting and trafficking. Exp. Mol. Med. 2019, 51, 1-12. [CrossRef] [PubMed] 